\title{
Accuracy and Spatial Pattern Assessment of Forest Cover change Datasets in Central Kalimantan
}

\author{
Sanjiwana Arjasakusuma, Uji Astrono Pribadi and Gilang Aria Seta
}

Received: 2018-06-03 / Revision: 2018-09-21 / Accapted: 2018-10-19

(c) 2018. Faculty of Geography UGM and The Indonesian Geographers Association

\begin{abstract}
The accurate information of forest cover change is important to measure the amount of carbon release and sink. The newly-available remote sensing based products and method such as Daichi Global Forest/Non-Forest (GFNF), Global Forest Change (GFC) datasets and Semi-automatic Claslite systems offers the benefit to derive these information in a quick and simple manner. We measured the accuracy by constructing area-proportion error matrix from 388 random sample points and assessed the consistency analysis by looking at the spatial pattern of deforestation and regrowth from built-up area, roads, and rivers from 2010 - 2015 in Katingan district, Central Kalimantan. Accuracy assessment showed that those 3 datasets indicate low to medium accuracy level in which the highest accuracy was achieved by Claslite who produced $71 \% \pm 5 \%$ of overall accuracy. The consistency analysis provides a similar spatial pattern of deforestation and regrowth measured from the road, river, and built-up area though their distance sensitivity are different one to another.
\end{abstract}

Keywords: Area-proportion matrix, Deforestation, Gain, Remote Sensing.

Abstrak Informasi akurat tentang perubahan penutup hutan adalah penting untuk mengukur jumlah karbon yang hilang dan yang diserap. Data penginderaan jauh terbaru berupa data dan metode dari antara lain, Daichi Forest/Non-Forest (FNF), Global Forest Change (GFC), and semi-otomatis ClasLite system menawarkan keuntungan untuk mendapatkan informasi tersebut dengan mudah dan cepat. Pada penelitian ini, kami mengukur akurasi dengan menggunakan proporsi luasan matriks kesalahan disusun dari 388 titik sampel acak dan mengkaji tingkat kekonsistenan dengan melihat pola spasial dari kelas deforestasi dan aforestasi pada tahun 2010 - 2015 terhadap data lahan terbangun, jalan dan sungai di Katingan, Kalimantan Tengah. Penilaian akurasi menunjukkan bahwa 3 data tersebut menunjukkan level akurasi rendah sampai menengah dengan akurasi tertinggi diperoleh dengan menggunakan metode ClasLite yang mendapatkan akurasi total sebesar $71 \% \pm 5 \%$. Selanjutnya, analisa konsistensi pola spasial menunjukkan pola yang seragam dari deforestasi dan aforestasi terhadap jalan, sungai dan lahan terbangun meskipun sensitivitas terhadap jaraknya berbeda.

Kata kunci: Matriks Proporsi Area, Deforestasi, Aforestasi, Penginderaan Jauh

\section{Introduction}

Deforestation and forest degradation are known as one of the major causes of environmental threats globally. In South-East Asia, between 1990 - 1997, annual forests loss reach up to 2.5 billion ha and only gained 0.5 billion ha annually (Achard et al. 2002). A newer study from Margono et al (2014), concluded that aroung 6 Million ha of primary forest in Indonesia has lost during 2000 - 2012, which was bigger than the forest loss in Brazil. Indonesia, as part of South-East Asia, is recognized for the high amount of carbon stocks and a wide range of biodiversity in its tropical forests, where forests loss in this region would result in a major loss of ecosystem services (Miettinen et al. 2011).

Despite the high loss of forests cover, biomass accumulation is being considered as a way to reclaim carbon loss during the forest growth processes (Pan et al. 2011). To assess the trade-off between the

@ 2018 by the authors. Licensee Indonesian Journal of Geography, Indonesia.
This article is an open access article distributed under the terms and conditions of the Creative Commons
Attribution(CC BY NC) licensehttps://creativecommons.org/licenses/by-nc/4.0/.
Sanjiwana Arjasakusuma
Faculty of Geography, Universitas Gadjah Mada, Indonesia
Uji Astrono Pribadi and Gilang Aria Seta
Center for International Forestry Research (CIFOR), Situ Gede, Sindang Barang, Bogor
(Barat) 16115, Indonesia
Correspondent email:Sanjiwana.arjasakusuma@uqconnect.edu.au

carbon release (deforestation) and carbon sink (forest gain), proper technology is needed to do an accurate measurement and continual monitoring purposes.

DeFries et al (2002) suggested that the use of satellite imagery is fit to monitor large areas regularly, in which it would be useful to map the forest cover change during the certain period of time. However, an improvement is required to fill a gap of measurement between remote sensing data and forest inventory (Dong et al. 2003; Pan et al. 2011). Recent advancement in remote sensing data and methods also require further exploration to select proper data in conducting quantitative analysis.

The methods to detect forest cover change and to distinguish deforestation and forests growth were typically conducted by either running a transformation of vegetation index, multispectral analysis and classification on the satellite imagery or manually delineating the imagery from visual interpretation (Singh 1989; Copping et al., 2002). Most of the studies such as Green and Sussman (1990); Skole and Tucker (1993); Shimabukuro et al, (1998); Duveiller et al. (2008); Souza Jr et al. (2013) and many more, used Landsat data in $30 \mathrm{~m}$ spatial resolution for mapping deforestation and forest degradation due to the relatively high spatial and spectral resolution, long data archive, 


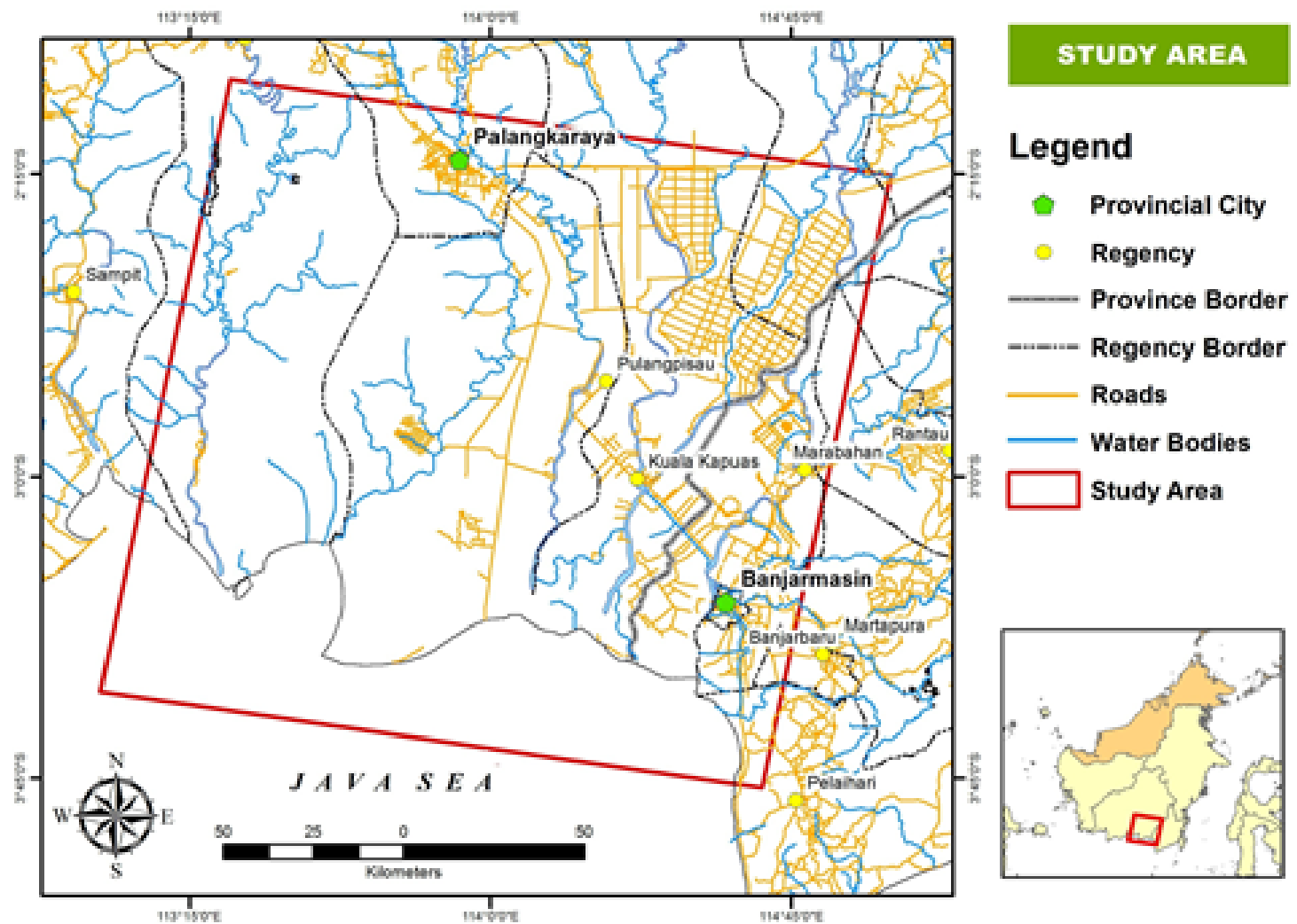

(Data source: Indonesia Geospatial Agency, 2011)

Figure 1. Study area in the Central Kalimantan Province, Indonesia

and its revisit time in 16 days that allow for intensive monitoring purpose.

Recently, various end-products of deforestation analysis such as Global forest-non forest (GFNF) data (Shimada et al. 2014) and global forest cover (GFC) data (Hansen et al. 2013) has been published. Moreover, a semi-automated framework namely Claslite has been developed by Asner et al. (2009) to identify deforestation from imagery. These potential data and methods are able to detect forest cover changes in spatial resolution of $25 \mathrm{~m}$ for GFNF data and $30 \mathrm{~m}$ for GFC and Claslite when Landsat data was used.

With the variety of available methods for detecting deforestation and afforestation data, the use of consistent method and measuring its output accuracy become essential in the monitoring process (DeFries et al. 2007). This study aims to measure the accuracy of forest cover change from the GFNF data and by using the Claslite method for mapping loss and gain data. The consistency of spatial distribution was also measured to see whether the final maps produced from the analysis depict similar spatial pattern to summarize the triggering factors of deforestation.

The Landsat scene path/row:118/062 were used for study, it covered the southern part of Borneo Island (Figure. 1), where there are two big cities exists in the northwest (Palangkaraya), and in the southeast (Banjarmasin) of Borneo Island. The study area is a lowland area dominated by peat forest and agricultural land. The peat soil in this area are mostly classified as deep peat with more than 4-meter depth (Wahyunto, 2004).

\section{The Methods}

We used three datasets to map forests loss and forests gain, the first two datasets are the end-product of GFNF data in the period from 2010 to 2015; the third dataset is GFC data covering the annual forests loss and and accumulative forests gain from 2000 2014. Additionally, Claslite system was used to produce deforestation map and forest/non forest map, then used these two information to calculate forests gain. Brief explanation of the ClasLite method was provided in the next section.

A cloud-free imagery from Landsat 5 and 8 acquisitioned in February 2010 and August 2015 were used to match the observation time of GFNF and GFC datasets.

\section{Forest Change from GFNF}

Simple raster algebra were performed to derive deforestation and gain data from GFNF datasets. The single year GFNF data already record the information of Forest and Non Forest so that mapping forest gain and loss can be performed by looking at the expansion and the retraction of forest area between 2010 and 2015 . 
1.)
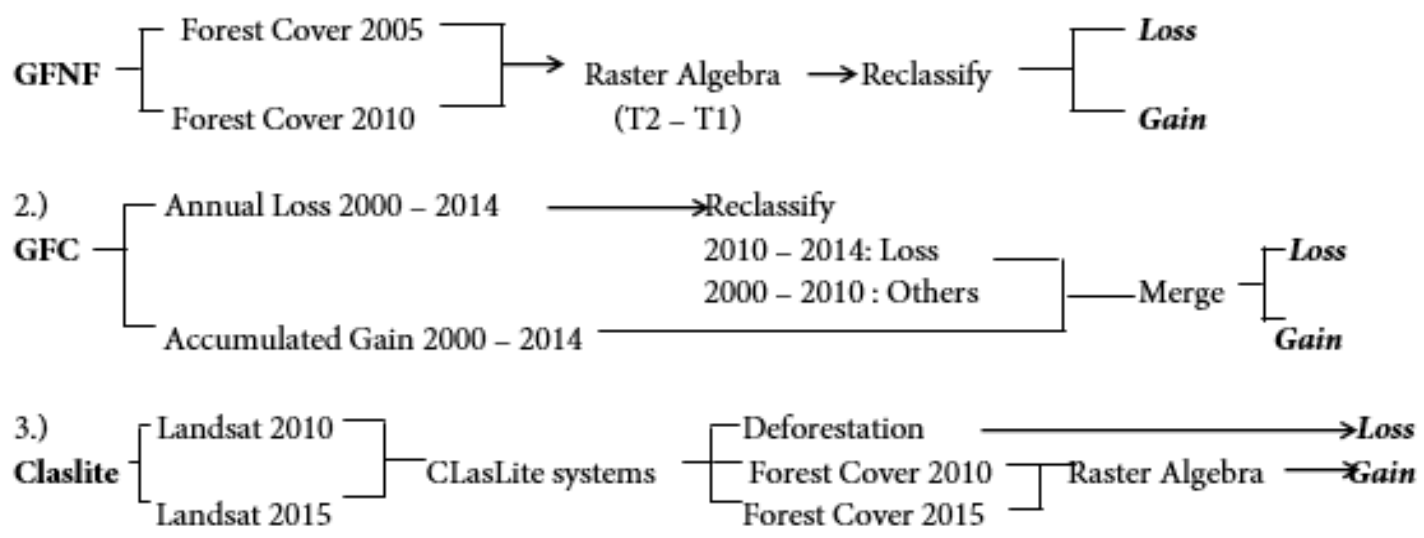

Figure 2. Image processing workflow to generate Loss and Gain class from GFNF, GFC and Claslite

\section{Forest Change from GFC}

Since the loss and gain data were already provided by GFC datasets, loss and gain map were produced by merging the the annual loss and gain data within 2010 -2014 .

\section{Forest Change from ClasLite}

In Claslite system, mapping of forests cover change was performed by identifying the fraction of photosynthetic vegetation (PV), non-photosynthetic vegetation (NPV) and bare substrate (BS) using the Auto-MCU Algorithm (Asner et al., 2009). This system also produces forest map indicated by $\mathrm{PV}$ fraction above $80 \%$.. This forest map was used to detect the forest gain area by identifying the expansion of the forest areas at 2010 and 2015. To map deforestation, the pre-defined tree condition was employed automatically to detect deforestation between 2010 and 2015 Overall image processing steps can be seen from Figure 2.

\section{Accuracy Assessment}

The accuracy assessment was performed by using a set of validation samples acquired from visual interpretation. The minimum number of sample to do an accuracy assessment was produced using Cochran (1973) as cited in Olofsson et al. (2013). The standard error of 0.01 for deforestation and gain classes; and 0.03 for the remaining classes were applied. Lower value of standard error of the remaining classes was selected to reduce the number of samples produced. To measure the overall accuracy, further error matrix was constructed using the area proportion based on the error matrix calculation from Olofsson et al. (2013). The error matrix is similar to the conventional error matrix however, the producers accuracy and users accuracy are supplemented with their specified confidence intervals (CI). The CI was formulated at $95 \%$ level of confidence as 1.96 of the square root of the estimated variance. Details of calculation can be found in Olofsson et al. (2014). The usage of CI can give better estimation of the resulted accuracy of the resulted map.

\section{Spatial Pattern Assessment}

Euclidean distance analysis was used to see the maximum distance from the related features of deforestation. These features was defined as man-made and natural infrastructures such as roads (all type of roads), settlements (urban built-up), and rivers (all type of water bodies, i.e. irrigation channels, lakes and all type of rivers) taken from Baseline map of Indonesia (2011) with 1:50.000 scale, acquired from BIG (Indonesia Geospatial Agency). Those factors were chosen to indicate the human-environment interaction that might cause theforest cover change. The analysis were conducted by reclassifying 30-meter pixel resolution into $1 \mathrm{~km}$ pixel resolution. In the following step, the measurement of the spatial consistency of deforestation was performed by conducting zonal statistical analysis. During this phase, the results from distance analysis and each deforestation data was imposed to determine the scale of deforestation associated with features distance from the forests.

\section{Result and Discussion \\ Forest Cover Change Map}

The image processing steps produced three classes: deforestation, gain, and other class. However, Claslite system seems to detect larger area of deforestation $(11,77 \%)$ and forests gain $(10.46 \%)$ from the whole study area which was two to five times larger than the area of deforestation and forests gain detected from GFNF and GFC data (table 1). It is also associated with Claslite system which detects and masks clouds, shadows, and water bodies from the imagery. Some area needs to be clipped and thus decrease the size of total area to be analyzed. The different calculation of the size of deforestation and gain area produced in those datasets needs to be addressed properly by pointing the level of accuracy for each map so that the data qualities can be concluded. 
Indonesian Journal of Geography, Vol. 50. No. 2, December $2018: 222$ - 227

Table 1. Total area of deforestation, forests gain, and other classes

\begin{tabular}{lllllll}
\hline \multicolumn{1}{c}{ Data } & \multicolumn{2}{c}{ GFNF } & \multicolumn{2}{c}{ GFC } & \multicolumn{2}{c}{ Claslite } \\
\hline Class & Area (ha) & $\%$ & Area (ha) & $\%$ & Area (ha) & $\%$ \\
Deforestation & 65106 & 3,55 & 112322 & 5,61 & 208525 & 11,77 \\
Gain & 67279 & 3,67 & 49101 & 2,14 & 185235 & 10,46 \\
Other & 1700490 & 92,78 & 1800085 & 92,25 & 1377834 & 77,77 \\
Total & 1832876,196 & 100,00 & 1961507,809 & 100,00 & 1771594,65 & 100,00 \\
\hline \multicolumn{2}{c}{ Source : Secondary data processing }
\end{tabular}

Table 2. Number of samples and its allocation before and after adjusted to meet the minimum number of validation points based on Cochran, 1973 as cited in Olofsson et al. 2013 equation

\begin{tabular}{lcccccc}
\hline Data & \multicolumn{3}{c}{ Initial Sample Allocation } & \multicolumn{3}{c}{ Adjusted Sample Allocation } \\
\hline Class & GFNF & GFC & Claslite & GFNF & GFC & Claslite \\
Deforestation & 70 & 16 & 23 & 77 & 70 & 72 \\
Gain & 55 & 5 & 27 & 61 & 55 & 73 \\
Other & 97 & 201 & 172 & 250 & 263 & 243 \\
Total Sample & & 222 & & & 388 & \\
\hline
\end{tabular}

Source : secondary data processing

Table 3. Level of accuracy for loss, gain and other classes in GFNF, GFC, and Claslite map

\begin{tabular}{lcccrrr}
\hline Data & \multicolumn{2}{c}{ GFNF } & \multicolumn{2}{c}{ GFC } & \multicolumn{2}{c}{ Claslite } \\
\hline Class & UA (\%) & PA (\%) & UA (\%) & PA (\%) & UA (\%) & PA(\%) \\
Loss & $23 \pm 10$ & $5 \pm 2$ & $48 \pm 18$ & $15 \pm 6$ & $71 \pm 11$ & $67 \pm 12$ \\
Gain & $28 \pm 11$ & $4 \pm 2$ & $41 \pm 14$ & $5 \pm 2$ & $52 \pm 12$ & $24 \pm-6$ \\
Other & $58 \pm 6$ & $92 \pm 1$ & $62 \pm 5$ & $94 \pm 2$ & $73 \pm 6$ & $88 \pm 3$ \\
OA (\%) & $56 \pm 6$ & \multicolumn{3}{c}{$61 \pm 5$} & $71 \pm 5$ \\
\hline
\end{tabular}

${ }^{\star}$ UA : User's accuracy, PA : Producer's accuracy, OA : Overall accuracy

Source : secondary data processing

Accuracy Assessment Analysis

The minimum number of validation points calculated using the mean area of deforestation, gain and other classes from GFNF, GFC and Claslite counts up to 222 points with the highest number of points are distributed in other category due to their dominance in the scene. Since the same validation points were used in different forest change maps, there was an unbalance allocation of validation points found among classes if the same points were applied to different maps. To get fair distribution throughout the three maps, we added randomly distributed points to classes which have less points than the minimum number of validation points which are 70 samples for loss, 55 for gain, and 97 for other categories. This process gave 166 additional points which sums up to 388 points used in the validation process as summarized in Table 2. The 388 validation points were labeled according to visual interpretation of Landsat data used in Claslite analysis. The results were then used to construct the area-proportion of error matrix for accuracy assessment. From the results obtained (Table. 3), it showed that Claslite produced the most accurate map with an overall accuracy followed by GFC and GFNF datasets. The superiority of Claslite was demonstrated and showed by several comparison studies such as from Thieme et al. (2015), Dlamini (2017) and Arjasakusuma et al. (2018). From each individual class, it also showed that user can employ a better Claslite map to find loss information in the field with higher possibility of obtaining real forests loss information.

The overall medium user accuracy was also accompanied by the relatively similar level of producer's accuracy of $67 \% \pm 12 \%$. Though, GFNF dataset produced by radar backscatter produced the lowest value of overall and individual class accuracy for deforestation and gain data. GFC dataset on the other hand produced medium overall accuracies with $61 \% \pm 5 \%$. However, producer's accuracies in the accuracy assessment was poor. In overall, mapping forests gain from satellite imageries still remains a big challenge where current end-products and methods are still limited to produce forests gain map with better accuracy.

The lowest accuracy from GFNF data which was originally derived from PALSAR data is surprising since numerous study has demonstrated the high accuracy (>90\%) of this data for mapping forest cover 


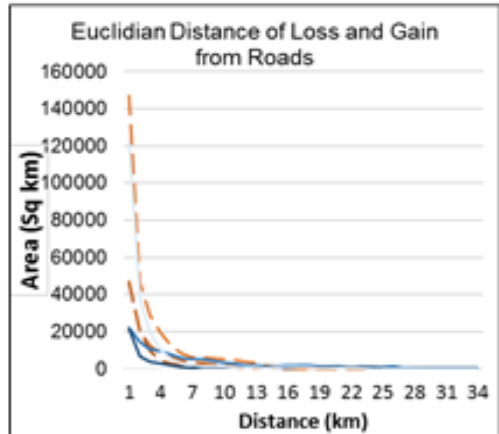

(A)

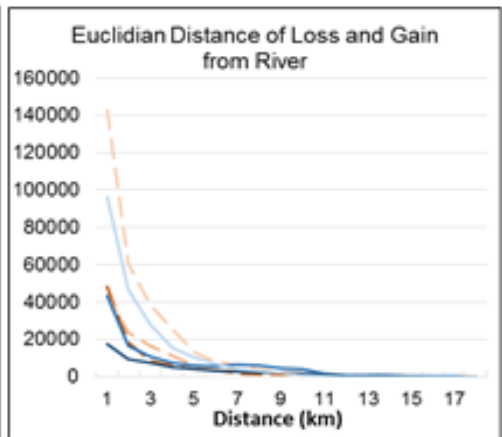

(B)

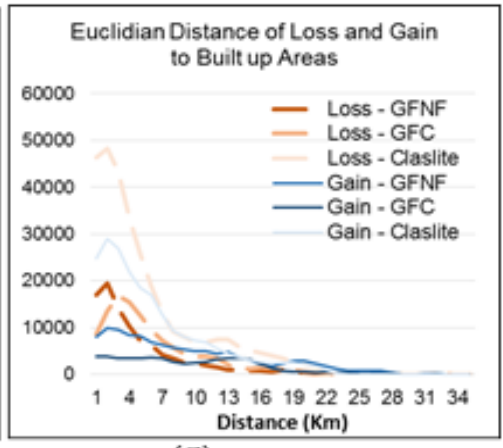

(C)

Figure 3. The distance sensitivity of loss and gain from three main features such as (A). Built-up area, (B). River, and (C). Roads. (source : secondary data processing)

(Shimada et al, 2014; Walker et al, 2010). Future study should identified the reason behind this low accuracy of GFNF data.

\section{Spatial Pattern Consistency}

The previous analysis shows that there are high differences of accuracy level produced by different forest cover change products. In this analysis, the distance sensitivity of deforestation and forests gain to roads, rivers, and built-up area were measured. Euclidean distance analysis show that changes in forests cover occurs within the radius between 40 to $50 \mathrm{~km}$ from these features. However, affected distance may vary depending on spatial pattern of each feature. Moreover, the results shows relatively similar pattern of forests loss and gain where increasing distance from each features means there are less pattern of forests loss and more forests gain. Most of forests gain area were deforested in the past and currently managed as cropland, which explained gain cycle detected from the maps close to the related features of deforestation. The distance graphs show different distance pattern where general pattern is relatively the same. The pattern indicates that most of forests losses and forests gains are located in large area of agricultural land such as paddy field and plantation which need access to irrigation channel and roads. The result of statistical analysis also shows that there are consistent patterns of deforestation though distance values may vary in different forest maps. Based on our analysis, from the potential distance of 40 - 50 kilometers, the farthest point that deforestation can occur are within the radius of 18 kilometers from rivers, 34 kilometers from roads, and 35 kilometers from built-up areas (Figure. 3). Moreover, distance sensitivity of rivers and roads reached its peak in the first kilometer, except for built-up area which peaked in $2-3$ kilometers radius. This indicates that roads and rivers provides a better access for transporting the logged trees. Therefore, forest near to the roads and rivers might have higher risk of deforestation. This finding is similar to the conclusion of the study from Veldkamp et al. (1992) in Costa rica and Barber et al (2014) in Amazon which emphasized the role of river and road to the deforestation.

\section{Conclusion}

Based on the result produced from the accuracy assessment performed in this study, it was concluded that mapping the forests loss in medium resolution by using Claslite can be done in a quick and simple manner compared to using GFNF and GFC datasets. However, it was also noticed that mapping forests gain with Claslite gives a low accuracy and requires further attention to provide more accurate results. Spatial consistency assessment showed that those data gave similar spatial pattern for various distances in different maps. It indicates that these maps can be used not only to analyze general pattern of forests loss and forests gain but also help to identify the main drivers of forest cover change. However, the level of detail from quantitative distance analysis to calculate forests loss and forests gain derived using remote sensing methods needs to address the accuracy of mapped objects as low accuracy might lead to the inaccurate conclusion of the distance.

\section{Acknowledgement}

The authors would like to thank USGS for providing the Landsat Imagery, JAXA for the DAICHI Forest/Non Forest (FNF) data, Hansen/UMD/Google/ USGS/NASA for Global Forest Change (GFC) data and Carnegie Institution for Science (CIS) for providing the ClasLite software.

\section{References}

Achard F, Eva HD, Stibig H-J, Mayaux P, Gallego J, Richards T, Malingreau J-P (2002) Determination of deforestation rates of the world' $s$ humid tropical forests Science 297:999-1002 doi:10.1126/ science. 1070656

Arjasakusuma S, Kamal M, Hafizt M, Forestriko HF (2018) Local-scale accuracy assessment of vegetation cover change maps derived from Global Forest Change data, ClasLite, and supervised classifications: case study at part of Riau Province, Indonesia Applied Geomatics:1-13

Asner GP, Knapp DE, Balaji A, Paez-Acosta G (2009) Automated mapping of tropical deforestation and forest degradation: CLASlite Journal 
of Applied Remote Sensing 3:33543-33543 doi: $10.1117 / 1.3223675$

Barber CP, Cochrane MA, Souza Jr CM, Laurance WF (2014) Roads, deforestation, and the mitigating effect of protected areas in the Amazon Biological conservation 177:203-209

Coppin P, Lambin E, Jonckheere I, Muys B (2002) Digital change detection methods in natural ecosystem monitoring: A review. In: Analysis of multi-temporal remote sensing images. World Scientific, pp 3-36

DeFries R, Achard F, Brown S, Herold M, Murdiyarso D, Schlamadinger B, de Souza C (2007) Earth observations for estimating greenhouse gas emissions from deforestation in developing countries Environmental Science \& Policy 10:385394 doi:10.1016/j.envsci.2007.01.010

DeFries RS, Houghton RA, Hansen MC, Field CB, Skole D, Townshend J (2002) Carbon emissions from tropical deforestation and regrowth based on satellite observations for the 1980s and 1990s Proceedings of the National Academy of Sciences of the United States of America 99:14256-14261 doi:10.1073/pnas.182560099

Dlamini WM (2017) Mapping forest and woodland loss in Swaziland: 1990-2015 Remote Sensing Applications: Society and Environment 5:45-53

Dong J et al. (2003) Remote sensing estimates of boreal and temperate forest woody biomass: Carbon pools, sources, and sinks Remote Sensing of Environment 84:393-410 doi:10.1016/S0034-4257(02)00130-X

Duveiller G, Defourny P, Desclée B, Mayaux P (2008) Deforestation in Central Africa: Estimates at regional, national and landscape levels by advanced processing of systematically-distributed Landsat extracts Remote Sensing of Environment 112:19691981

Green GM, Sussman RW (1990) Deforestation history of the eastern rain forests of Madagascar from satellite images Science 248:212-215

Hansen MCPVPRMMHSATATDTSVSSJGT, Justice CO, Townshend JRG (2013) High-Resolution Global Maps of 21st-Century Forest Cover Change (15 November): 850-53 Science 342:850-853 doi:Accessed through Global Forest Watch on [date]. www.globalforestwatch.org

Margono BA, Potapov PV, Turubanova S, Stolle F, Hansen MC (2014) Primary forest cover loss in Indonesia over 2000-2012 Nature Climate Change 4:730 doi:10.1038/nclimate2277https://www. nature.com/articles/nclimate2277\#supplementaryinformation

Miettinen J, Shi C, Liew SC (2011) Deforestation rates in insular Southeast Asia between 2000 and 2010 Global Change Biology 17:2261-2270 doi:10.1111/ j.1365-2486.2011.02398.x

Olofsson P, Foody GM, Herold M, Stehman SV, Woodcock CE, Wulder MA (2014) Good practices for estimating area and assessing accuracy of land change Remote Sensing of Environment 148:42-57

Olofsson P, Foody GM, Stehman SV, Woodcock CE (2013) Making better use of accuracy data in land change studies: Estimating accuracy and area and quantifying uncertainty using stratified estimation Remote Sensing of Environment 129:122-131 doi:10.1016/j.rse.2012.10.031

Pan Y et al. (2011) A large and persistent carbon sink in the world's forests Science (New York, NY) 333:988-993 doi:10.1126/science.1201609

Shimabukuro YE, Batista G, Mello E, Moreira J, Duarte $\mathrm{V}$ (1998) Using shade fraction image segmentation to evaluate deforestation in Landsat Thematic Mapper images of the Amazon region International Journal of Remote Sensing 19:535-541

Shimada M, Itoh T, Motooka T, Watanabe M, Shiraishi T, Thapa R, Lucas R (2014) New global forest/ non-forest maps from ALOS PALSAR data (20072010) Remote Sensing of Environment 155:13-31 doi:10.1016/j.rse.2014.04.014

Singh A (1989) Review article digital change detection techniques using remotely-sensed data International journal of remote sensing 10:9891003

Skole D, Tucker C (1993) Tropical deforestation and habitat fragmentation in the Amazon: satellite data from 1978 to 1988 Science 260:1905-1910

Souza Jr CM et al. (2013) Ten-year Landsat classification of deforestation and forest degradation in the Brazilian Amazon Remote Sensing 5:5493-5513

Thieme A, McCartney S, Rogan J, Sangermano F, Wilkie D Using CLASlite to Map Deforestation in Makira Natural Protected Area, Madagascar. In: AGU Fall Meeting Abstracts, 2015.

Veldkamp E, Weitz AM, Staritsky I, Huising E (1992) Deforestation trends in the Atlantic Zone of Costa Rica: a case study Land Degradation \& Development 3:71-84

Wahyunto SR, Subagjo H (2004) Peta Sebaran Lahan Gambut, Luas dan Kandungan Karbon di Kalimantan/Map of Peatland Distribution Area and Carbon Content in Kalimantan, 2000-2002 Wetlands International-Indonesia Programme \& Wildlife Habitat Canada (WHC)

Walker WS, Stickler CM, Kellndorfer JM, Kirsch KM, Nepstad DC (2010) Large-area classification and mapping of forest and land cover in the Brazilian Amazon: A comparative analysis of ALOS/PALSAR and Landsat data sources IEEE Journal of Selected Topics in Applied Earth Observations and Remote Sensing 3:594-604 